\title{
The frame and name of the medical treatment and their influence on health decisions ${ }^{1}$
}

\author{
Kaja Damnjanović 2 \\ University of Belgrade, Faculty of Philosophy
}

\section{Sandra Ilić ${ }^{3}$}

University of Belgrade, Faculty of Philosophy, Department of Psychology, Laboratory for Experimental Psychology

\section{Predrag Teovanović}

University of Belgrade, Faculty for Special Education and Rehabilitation

Decisions about one's own health range from everyday easy ones, such as taking a vitamin pill, to those made in the situations of life-threatening diseases. When it comes to choosing treatments, patients have difficulty understanding statistical information about the possible outcomes of alternative treatments, such as probabilities and risks. These challenges are especially important in the context of the shared decision-making. The aim of this study was to examine the influence of the labelling of the treatment in risky choice decision tasks. The risky choice framing effect (FE) pertains to the systematic preference reversal because different aspects of formally identical situations are emphasized. In the present study, the participants made a forced choice between a nonrisky and risky treatment presented in terms of gains and losses. In the first condition surgery was the risky option and in the second it was radiation. In the third condition, the treatments' labels were replaced with 'A' and 'B'. Chi-square tests revealed a significant difference in the proportions of risky choices between the three conditions. The FE was registered only in the first and the second condition, and it was moderate and strong, respectively. When choosing between surgery and radiation, participants' choices were indeed influenced by the naming of the treatment, but not exclusively - they generally preferred surgery, and when it was offered in terms of losses, they preferred it even more.

Keywords: health decision, shared decision making, risky choice, framing effect, medical treatment, surgery, radiation, prospect theory, fuzzy-trace theory, patient

1 This paper is part of the project "Fundamental cognitive processes and functions" (179033) and "Identification, measurement and development of the cognitive and emotional competences important for a Europe-oriented society" (179018)

2 kdamnjan@f.bg.ac.rs

3 student master studija 


\section{Introduction}

Decision-making in the domain of health involves a complex social interaction between a clinician and the patient, varying on a continuum from the clinician-led, through shared, to patient-led (Coulter \& Collins, 2011). Clinician-led decision-making pertains to a practice in which a clinician, after either consulting or not consulting a patient, makes the decision for the patient. Conversely, patient-led decision-making pertains to a practice in which patients make decisions, after possibly having received information from the clinician (Slade, 2017). The middle position, where medical professionals and patients share available evidence, andin which patients are encouraged and even obligated to consider possibilities is labelled as the shared decision-making (Elwyn, Coulter, Laitner, Walker, Watson, \& Thomson, 2010). In such context, patients are expected to take responsibility and actively participate in making choices regarding their health (Reyna, Nelson, Han, Pignone, 2015).

In order to reach truly informed health-related decisions, patients should be able to understand and know how to use information presented to them (McNeil, Pauker, Sox, \& Tversky, 1982; Reyna \& Brainerd, 2007). However, previous research had consistently shown that when it comes to choosing treatments, patients have difficulty with understanding statistical information about the possible outcomes of alternative treatments, such as probabilities and risks (Ferrer \& Klein, 2015; Reyna \& Brainerd, 2007; Reyna \& Brainerd, 2008). Patients' risk perceptions are often unrealistic and affected by various factors, such as their level of numeracy (Peters, Västfjäll, Slovic, Mertz, Mazzocco, \& Dickert, 2006; Reyna \& Brainerd, 2008; Reyna, Nelson, Han, \& Dieckmann, 2009), previous experiences with the disease (Brewer, Weinstein, Cuite, \& Herrington, 2004)or emotions (Ferrer, Klein, Lerner, Reyna, \& Keltner, 2015). In line with this, health-related decisions that patients are supposed to make inherently involve a consideration of complex and often counterintuitive evidence (Appelbaum \& Grisso, 1988; Reyna et al., 2015; Petrova, Garcia-Retamero, \& Cokely, 2015; Reyna, 2008; Thokala, Devlin, Marsh, et al., 2016). As the complexity of the decision increases, people tend to simplify it by relying on simple heuristics, which leads to their decisions sometimes being poor and/or irrational (Payne, Bettman, \& Johnson, 1988). In other words, people whohave to makea decision regarding their health face a range of cognitive obstacles, which have been a topic of a large number of studies, especially those that investigated different cognitive biases (Blumenthal-Barby \& Krieger, 2015; Dawson \& Arkes, 1987; Ozdemir \& Finkelstein 2018; Saposnik, Redelmeier, Ruff, \& Tobler, 2016). 
A cognitive bias that has received a disproportionally large amount of attention in the domain of health is the framing effect (Blumenthal-Barby \& Krieger, 2015). The risky choice framing effect pertains to the systematic preference reversal (between sure and risky options) because different aspects, usually gains and losses, of formally identical situations (with regards to their expected values) are emphasized (Tversky \& Kahneman, 1981). More precisely, when the situation is presented in terms of gains (e.g. money earned), participants tend to choose the sure option (e.g. an option that ensures earning a specific amount of money). However, when the same situation is presented in terms of losses (e.g. money lost), participants tend to change their preference order and opt for risk, i.e. they choose a less certain or risky option (e.g. an option that leads to earning a greater amount of money, but with a probability lower than 1 ). Such preference reversal, from riskaverse to risk seeking (or vice versa) is labelled as the bidirectional framing effect. However, when there is no shift between preferences, but an upgrade to a more extreme preference augmenting the decision maker's already existing preference, which is the case when the decision maker's preferences regarding the content of the decision are unambiguous, the unidirectional framing effect occurs (Levin, Schnittjer, \& Thee, 1988; Reyna \& Brainerd, 1995; Wang, 1996a). Since the framing effects registered by using the tasks referring to the health domain differ indirection, consistency, and intensity from the framing effects yielded by the tasks referring to other domains of human life (Haward, Murphy, \& Lorenz, 2008; Huang \& Wang, 2010; Fagley \& Miller, 1997; Wang, 1996; Author, 2016), it has been inferred that distinct psychological mechanisms are employed when making decisions in different domains (Wang, 1996b). In other words, a health decision and a decision about buying a house might be equal in terms of, for example, the number of alternatives available, complexity or importance, but the psychological mechanisms employed in making the decision regarding one's health differ from the mechanisms employed when choosing among the alternatives regarding other domains of life. However, in the domain itself, the framing effects also differ due to different levels of involvement in the content of the decision. When the involvement in the content of the decision is higher, the bidirectional framing effects decrement and more stable unidirectional framing effects are registered (Huang \& Wang, 2010; Levin et al., 1988; Reyna \& Brainerd, 1995; Wang, 1996a).

Numerous theoretical models have been proposed with the aim of explaining the mechanisms underpinning the framing effects. The two most prominent arethe prospect theory (Kahneman \& Tversky, 1979) and the fuzzy-trace theory (Reyna \& Brainerd, 1995; Reyna \& Brainerd, 1991). In the prospect theory, Tversky and Kahneman define a decision frame as 
the decisionmakers' preconceptions in relation to acts and the possible consequences of a certain choice. The frame employed by the decision maker is partly determined by the formulation of the task and partly by his/ her own personal features (Tversky \& Kahneman, 1981). The key concepts of the prospect theory include two functions - the value function and the probability weighting function. The value function reflects the attitude of the decision maker towards the possible outcomes. The values are defined in terms of deviations from the reference point, i.e. gains and losses, and the objective and subjective value are associated through the DM's comparisons of the utilities of the options' outcomes. Preferences are ordered in such a way that a sure option is preferred in a positive frame, while a risky option is preferred in a negative frame. This 'not normatively rational' behaviour is due to the susceptibility to the influence of the given frame, and it is a consequence of transferring the decision makers' reference point.

Several cognitive models assume that cognitive processing is determined by the content and subjective importance of a problem. The domain in which the decision is embedded shapes thinking. The fuzzy-trace theory postulates that we prefer 'fuzzy' processing, or the most simple processing (Fischer \& Hawkins, 1993; Reyna \& Brainerd, 1995). It explains the framing effect as a result of the simplified processing of surface information, which operates at this simplified, surface level, extracting the gist of information (Reyna \& Brainerd, 1995; Reyna \& Brainerd, 1991, Reyna, Lloyd, \& Brainerd, 2003). For example, when information about probability is presented, a decision maker mentally represents the gist of that numerical information. The gist is qualitative and stored, coded, and taken over by the mechanisms different from those used for coding and storing verbatim information. For example, a sixty-year-old woman finds out that the risk for her to develop breast cancer is $25 \%$. The precise verbatim information is $22 \%$ of the risk, but the representation of the gist answers the question: 'What does $25 \%$ of the risk mean?'. The gist of this value can be interpreted as the 'low risk' in relation to 50-50 chances or as the 'high risk' $10 \%$, which could be the average risk for women of her age. Thus, the gist depends both on the contextual (e.g. her colleague suffered from breast cancer) and individual factors, like the level of numeracy (Reyna \& Brainerd, 2007). The same logic applies for the decisions regarding choosing 'the best' treatment from several alternative options. Thesurvival or death rates would be the verbatim information, but the gist of those values could be interpreted as high or low riskiness of the treatment based on some previous personal or by-proxy experience with those particular treatments (e.g. there may be someone who received chemotherapy and soon died). In other words, it is possible that in the situations in which patients are supposed to make a choice between different treatments the consistency, intensity and direction of the frame effect might depend on the decision 
makers' implicit notions or assumptions about the offered treatments, which could also be dubbed as narrative perceptions. More than three decades ago, McNeil and colleagues (McNeil et al., 1982) introduced this presumption when they found that one form of treatment (radiation) was less attractive than the other (surgery) when treatments were identified, as opposed to an experimental condition in which participants chose between two unidentified treatments (A and B). This finding indicated that people relied not only on the presented statistical data but also on their pre-existing beliefs regarding the offered treatments (McNeil et al., 1982). However, previous studies about framing in the domain of health aimed at plotting the ways of a precise presentation of notably numerical information and mapping errors in patient's decision-making yielded by such representations (Covey, 2007; McNeil et al., 1982; Moxey, O'Connell, McGettigan \& Henry, 2003). The notion that healthrelated decisions are influenced by the patients' beliefs about treatments has been somewhat neglected, albeit repeatedly proven correct in the qualitative analyses of decision-making in the health domain (Mazur \& Hickam, 1996; Steginga, Occhipinti, Gardiner, Yaxley, \& Heathcote, 2002), as well as some quantitative studies regarding medication adherence (Horne \& Weinman, 1999). It is also supported by the findings demonstrating the effect ofindepth consideration of positive and negative aspects of a certain treatment on framing effects (Almashat, Ayotte, Edelstein, \& Margrett, 2008; GarciaRetamero \& Galesic, 2010).

Based on the results of earlier research (Horne \& Weinman, 1999; McNeil et al., 1982; Mazur \& Hickam, 1996; Steginga et al., 2002) and our previous studies (Damnjanović \& Gvozdenović, 2016; Damnjanović, 2013) in which distinctively different patterns of framing effects were observed in the health domain itself, and based on the studies in which the unidirectional framing effect occurred because the decision makers' preferences regarding the content of the decision were unambiguous or the involvement in the content of the decision was high (Huang \& Wang, 2010; Levin et al., 1988; Reyna \& Brainerd, 1995; Wang, 1996a), we propose that the yielding of specific patterns of FEs in health decisions is related to the naming of treatments, and probably to the decision makers' implicit notions or assumptions about the given name.

Aim

The present study examines the effect of framing in the health domain by comparing the framing effects elicited in the experimental situations which differed intreatment labels. The aim was to present a detailed empirical description of the phenomenon by reintroducing and elaborating variations 
in the surface structure of the risky choice task (labels), which could prompt implicit notions or assumptions about different treatments. We also aimed at comparing the theoretical explanations of the results yielded by such manipulation, provided by two descriptive models of decision-making - the prospect theory and the fuzzy-trace theory. Finally, our aim was to refine the methodological confound inherent to the original McNeil's design, as it was often the case in the first applications of the JDM paradigm to medical decision-making.

\section{Method}

\section{Participants and procedure}

The sample consisted of 300 participants (mean age 21.5 years; $53 \%$ female), students at the University of XXX (blinded). The probability of detecting a statistically significant framing effect of the same size as reported by Tversky and Kahneman (1981), using a bivariate test (at the level $p<.01$ ) for the sample of 50 subjects per experimental group, amounts to $99.8 \%$.

Data were collected in six sessions in groups of around 50 subjects. Prior to stimuli presentation, a written consent for participation was obtained, and written as well as oral instructions were given. Subjects were then presented with a description of a hypothetical situation in which they imagined that they were told they hada severe illness. Their task was to choose one of the two offered treatments, by marking the preferred one. Each participant completed only one task.

\section{Stimuli and design}

All stimuli had the form of a risky-choice task. They consisted of a description of the situation with two possible solutions presented as two offered mutually exclusive options. Participants' task was to make an imaginary, forced choice between the two options: a non-risky (sure, S) and a risky $(\mathrm{R})$ one, equal with respect to their (expected) values. Probability of a positive outcome of the risky option was fixed at $75 \%$ survival rate. All stimuli are provided in Appendix A.

The study design was between subjects, 2(frames) x 3(contents). The frame factor had two levels: a positive and a negative frame of the two offered options. In other words, the same two options in each task were presented in terms of gains and in terms of losses. The second factor, task content, was formed as a combination of the options' riskiness and treatment 
labels/names, and had three levels: a classical task, an abstract version, and a classical task with the inverted options' meaning. By intersecting three levels of task content with two frames, three different pairs or six tasks were formed (Appendix A).

The first pair of tasks was the choice between two types of medical treatments: surgery and radiation. It was a modification of the classical task first used in the original study by McNeil and colleagues (McNeil et al., 1982) in which radiation, a non-invasive treatment option, was considered sure and surgery, an invasive treatment option, was considered risky. These are well-established options, frequently used in research papers on framing in the health related decision-making domain (Bigman, Cappella, \& Hornik, 2010; Levin et al., 1988; Levin, Gaeth, Schreiber, \& Lauriola, 2002). The content of other two types of tasks was either the same, with treatment options which changed places so that the previously risky option became the sure one and vice versa (Type 3), or it was changed so that the offered treatment options were presented in an abstract manner, meaning that the names of treatments were omitted and replaced with labels A for a sure option, and B for a risky option (Type 2). Each of these three types of tasks had two versions, corresponding to two levels of the frame factor. The percentage of risky choices was used as a measure of the dependent variable, which is usual in framing effect studies.

\section{Results}

\section{Risky choice}

The risky choice percentages, confidence intervals and chi-square statistics for the framing effects obtained in six experimental groups are presented in Table 1 and Graph 1. Statistically significant percentage of risky choices in both frames was registered in three out of six tasks, while the significant percentage of sure choices was registered in one task. The percentage of subjects who chose the risky option in all tasks (at all levels of the content and frame) is $56 \%(95 \% \mathrm{CI}[47.50,58.39])$. In the classical pair of tasks, the percentage of risky choices is $76 \%(95 \%$ CI $[66.71,83.36])$. While confidence intervals in the abstract pair of tasks pin on indifference $(\mathrm{P}=58 \%$; $95 \% \mathrm{CI}$ $[48.20,67.21])$, the aversion to risky choices was registered in the inverted pair of tasks $(\mathrm{P}=35 \%$; 95\% CI $[26.36,44.75])$. The results of chi-square tests reveal a statistically significant difference between the proportion of risky choices between the classical and inverted tasks $\left(\chi^{2}(1, \mathrm{~N}=200)=24.03\right.$, $p<.001)$, between the abstract and inverted $\left(\chi^{2}(1, \mathrm{~N}=200)=10.63, p=.001\right)$, and between the classical and abstract tasks $\left(\chi^{2}(1, \mathrm{~N}=200)=7.33, \mathrm{p}=.006\right)$. 
Table 1.

Group differences in risk preference for the positively and negatively framed outcomes of the decision problems in three pairs of tasks

\begin{tabular}{|c|c|c|c|c|c|c|c|c|}
\hline \multirow{2}{*}{ Task content } & \multirow{2}{*}{$\begin{array}{l}\text { Framing of } \\
\text { the outcome }\end{array}$} & \multicolumn{3}{|c|}{ Risky choice } & \multicolumn{4}{|c|}{ Framing effect } \\
\hline & & $\mathrm{P}(\%)$ & $95 \%$ CI - & $95 \% \mathrm{CI}+$ & $x^{2}$ & $\mathrm{r}_{\varphi}$ & $\mathrm{p}$ & Conclusion \\
\hline \multirow{2}{*}{ Classical } & Survive & 66 & 52.15 & 77.56 & \multirow{2}{*}{5.48} & \multirow{2}{*}{.23} & \multirow{2}{*}{.019} & \multirow{2}{*}{ One-way } \\
\hline & Die & 86 & 73.91 & 93.05 & & & & \\
\hline \multirow{2}{*}{ Inverted } & Survive & 16 & 8.34 & 28.51 & \multirow{2}{*}{15.87} & \multirow{2}{*}{.40} & \multirow{2}{*}{.001} & \multirow{2}{*}{ Two-way } \\
\hline & Die & 54 & 40.40 & 67.03 & & & & \\
\hline \multirow{2}{*}{ Abstract } & Survive & 52 & 38.51 & 65.20 & \multirow{2}{*}{1.48} & \multirow{2}{*}{.12} & \multirow{2}{*}{.224} & \multirow{2}{*}{$\begin{array}{c}\text { Non- } \\
\text { significant }\end{array}$} \\
\hline & Die & 64 & 50.14 & 75.86 & & & & \\
\hline
\end{tabular}

Note. Each experimental group consisted of 50 subjects. Classical - Surgery was the risky option; Inverted - Radiation was the risky option; P - percentage; 95\% CI- and 95\% $\mathrm{CI}+$ denote the lower and upper boundaries of the $95 \%$ confidence interval estimated byWilson's procedure (Wilson, 1927); $\chi^{2}-$ Chi-square statistic; $r_{\varphi}-$ mean square contingencycoefficient; $\mathrm{p}-\boldsymbol{\alpha}$ level

\section{Framing effect}

A statistically significant tendency to choose the risky option is $44.67 \%$ $(95 \%$ CI $[36.95,52.66])$ in the positive frame, and 68\% (95\% CI [60.17, 74.94]) in the negative frame. The difference between the percentages of risky choices between the two frames is statistically significant $\left(\chi^{2}(1, \mathrm{~N}=300)=16.60, r_{\varphi}=\right.$ $.24, p<.001)$. This effect, however, is not identical atall levels of the content of the task factor. The inverted pair of tasks elicited a strong framing effect; the classical pair of tasks elicited a moderate framing effect, while in the abstract pair of tasks the framing effect was not registered at all, as shown in Graph 1. In brief, the registered main framing effect is not representative for all levels of the task content factor. Overall, surgery was chosen considerably more than radiation, regardless of whether it had been described using negative (death rates) or positive (survival rates) wording, or whether the attributed risks hadbeen described as higher or lower compared to radiation $\left(\chi^{2}(1\right.$, $\mathrm{N}=200)=6.40, p=.0109$ ). 


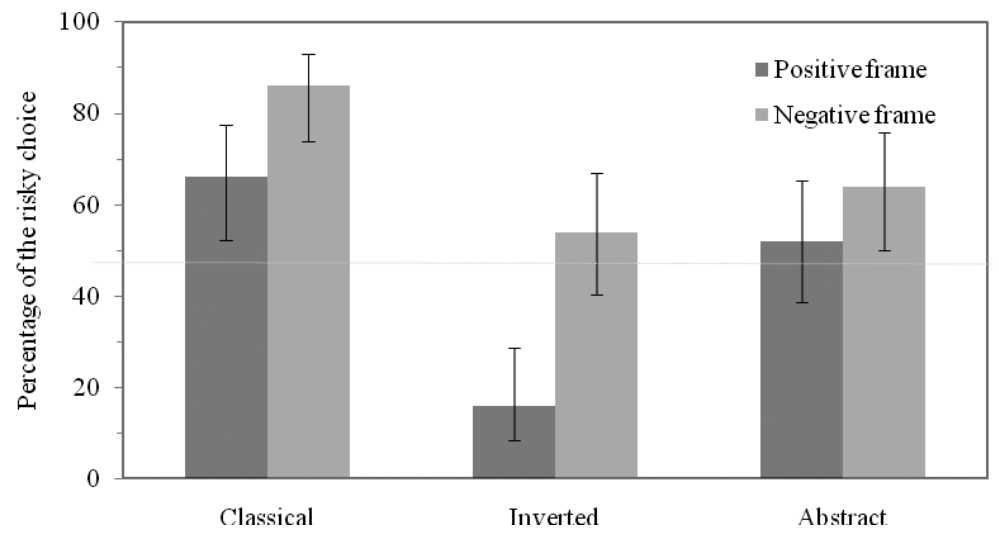

Graph 1. Choice of the risky option as the function of the content of the task

\section{Discussion}

In this paper, we reported on the results of the experiment investigating hypothetical treatment choices (radiation vs. surgery) of 300 young adult university students. The manipulated aspects of the choices were gain vs. loss framing, and the name or the content of the treatment option. The study investigated the question of decisions about one's own health and could have some important practical implications for understanding patient preferences for treatment, particularly in the shared decision-making contexts. For this reason, understanding the biases that patients may have based on framing is an important aim for research.

The results show that there was no framing effect in the abstract version (no labels of radiation or surgery) while the framing effects in the versions that labelled treatment options as radiation or surgery were registered. Interestingly, the condition that produced the strongest "preference reversal" was the inverted content condition, when radiation was presented as safe and surgery as risky. In the first, classical pair of tasks (McNeil et al., 1982), where radiation represented the sure option and surgery the risky one, in both frames, the choice of the risky option (surgery) was more common than the choice of the sure option, albeit risk preference was amplified by the negative frame. In that condition, a strong unidirectional framing effect was registered. This pattern is in line with the findings of previous studies concerned with the relation between the direction of the framing effect and personal involvement in the decision. Preferences regarding one's own health are highly involving and, therefore, not influenced by the frame in terms of the preference reversal or inversion, but in terms of the intensity of preferences (Levin et al., 1988; Reyna \& Brainerd, 1995; Huang \& Wang, 2010). This indicates that participants have unambiguous preference (Wang, 1996a) for surgery when they are faced with the choice between surgery and radiation. 
In the inverted pair of tasks, where surgery represented the sure option and radiation the risky one, in the positive frame, the percentage of participants who chose surgery (sure option) was very high ( $84 \%$ chose surgery), while in the negative frame more than half of the participants chose radiation (risky option), which gives a classical bidirectional framing effect on the group level. This particular finding is in accordance with the prospect theory, according to which the decision maker prefers a sure option (surgery) in the positive frame, and a risky option (radiation) in the negative frame due to the susceptibility to the influence of the given frame, and as a consequence of transferring the decision makers' reference point (Kahneman \& Tversky, 1979; Tversky \& Kahneman, 1981).

However, taken altogether, surgery was chosen considerably more than radiation, regardless of whether it was represented as the sure or the risky alternative. Along with the differences of the observed changes in the percentages of risky alternative choices induced by the frame, this finding implies that when participants are faced with the choice between surgery and radiation their choices are, to an extent, influenced by the frame, but also by their personal beliefs, as they generally prefer surgery, and when it is offered in terms of death rates (losses) they tend to prefer it even more.

In order to double confirm that the registered preference and the framing effect are indeed moderated by the implicit assumptions and attitudes towards different treatments held by the decision makers, we omitted the treatment labels, -which implied that participants could no longer prefer one treatment over the other. In this condition, we gave the treatments abstract names, A and $\mathrm{B}$, and then compared the percentages of risky choices in this condition with those registered in the classical and inverted pairs of tasks.

When participants were presented with treatments with abstract labels, the percentage of risky choices dropped significantly in both frames compared to the classical pair of tasks where surgery was the risky option: in the positive frame by $14 \%$ (from $66 \%$ to $52 \%$ ) and in the negative by $22 \%$ (from $86 \%$ to $64 \%$ ). Moreover, the previously registered strong unidirectional framing effect disappeared, as the framing effect was not registered at all. Compared to the inverted pair of tasks where radiation was represented as the risky option, the percentage of risky choices increased by $36 \%$ (from $16 \%$ to $52 \%$ ) in the positive frame, and by $10 \%$ (from $54 \%$ to $64 \%$ ) in the negative frame. Taken altogether, when the names of treatments were omitted and replaced with neutral labels that supposedly did not trigger the implicit assumptions and attitudes towards treatments, the previously registered framing effects of any direction disappeared. Moreover, when the risky option changed names from 'surgery' through the abstract ' $\mathrm{B}$ ' and finally to 'radiation', the percentage of choices of that risky alternative significantly dropped, regardless of the 
frame. In other words, participants preferred surgery and disliked radiation regardless of the risk assigned to them or the frame they were represented in.

A comparison of the registered changes in the choice patterns in the three conditions points towards a conclusion that the forced choice between two treatments is influenced not only by the riskiness of choice alternatives, information about possible outcomes of the treatments and positive or negative framing of the situation, but presumably also by pre-existing beliefs about treatments. This is in accordance with the findings of qualitative studies on patients' decision-making (Mazur \& Hickam, 1996; Steginga et al., 2002) and the correlational studies regarding medication adherence (Horne \& Weinman, 1999). The pre-existing attitudes and assumptions could have served as a risk factor for the influence of framing, which is also supported by some previous findings (Horne \& Weinman, 1999; McNeil et al., 1982). From the perspective of the fuzzy-trace theory (Reyna et al. 2015; Reyna \& Brainerd, 2007), the pre-existing beliefs influence the gist of the presented information (Reyna \& Brainerd, 1995; Reyna \& Brainerd, 1991, Reyna et al., 2003), which, as previously stated, could be interpreted as the narrative perceptions. This is what we recommend for further research. However, our results support the value function of the prospect theory (Kahneman \& Tversky, 1979; Tversky \& Kahneman, 1981) - higher percentages of risky choices were indeed registered in these health-related tasks when the word "dying" was used. The interpretation of our findings comprises a shift in the reference point, arising from the influence of participants' notions about the offered medical treatments.

The obtained findings add to the existing literature and findings about distinct characteristics of patients' decision-making. In the contexts of the shared or patient-led decision-making, patients are responsible for decisions regarding their own health (Reyna et al., 2015). Health-related decisions employ distinct psychological mechanisms compared to other domains of life (Damnjanović, 2013; Damnjanović \& Gvozdenović, 2016; Fagley \& Miller, 1997; Haward, Murphy, \& Lorenz, 2008; Huang \& Wang, 2010; Wang, 1996b; Wang, 1996) and are not simple at all (Appelbaum \& Grisso, 1988; Petrova, Garcia-Retamero, \& Cokely, 2015; Reyna, 2008; Reyna et al., 2015; Thokala et al., 2016). The reason lies in the fact that they are influenced by various factors, such as the patients' level of numeracy (Ferrer \& Klein, 2015; Peters et al., 2006; Reyna \& Brainerd, 2007; Reyna \& Brainerd, 2008; Reyna, et al., 2009), their emotions (Ferrer et al, 2015), previous experiences with the disease (Brewer et al., 2004), the level of involvement (Huang \& Wang, 2010; Levin et al., 1988; Reyna \& Brainerd, 1995; Wang, 1996a), the framing of the choice (McNeil et al., 1982), and, as it seems,thepatients' own implicit assumptions about treatments. Mapping errors in patients' judgments in 
the decisions made by different representation of numerical information (Covey, 2007; McNeil et al., 1982; Moxey et al., 2003) is not enough to make the patients' decisions more informed. If people's treatment preferences are under the influence of their pre-existing beliefs about treatments, then we must invest not only in clarifying statistical concepts, but also in educating patients and disputing potentially false beliefs about particular treatments. This notion is in line with the findings of previous studies which have indicated that not only do patients show increased willingness to participate in medical treatments when the information is presented to them so that they can understand it (Edwards, Elwyn, Covey, Matthews, \& Pill, 2001), but they are also less subject to framing after a more comprehensive reviewing of a certain treatment (Almashat et al., 2008; Garcia-Retamero \& Galesic, 2010). The importance of our findings can be demonstrated by the fact that different types of treatments have different outcome probabilities when applied to different kinds of diseases and in different patient groups. For example, surgery might be the best option for the patients with early-stage lung cancer who are otherwise healthy and represent good surgical candidates, but not for older patients or patients who are thought to have a high risk of surgical complications (Stokes et al., 2018). If the person from the latter group holds a strong preference for surgery, this person may choose surgery over a better course of treatment, and the specific wording of the choice might even amplify this preference. In other words, when presenting patients with alternative treatment options, their preference should be taken into account beforehand. Although we cannot modulate their emotions, previous experiences or the extent to which they are personally involved in the decision, we should be able to influence their attitudes towards and beliefs about specific treatments. For medical practitioners, the recommendation based on these findings would be to address the concerns specific to the treatment in question, and not only concerns about the disease.

Limitations. In the current study, we applied the JDM paradigm to medical decisions, with the context being that medical decisions most probably inherently come with a preference for or against a treatment. In our study, this approach is limited by the use of young adults as participants. Given that the aim of this study was, among other things, to shed light on patients' decisions in the context of shared decision-making, the use of presumably healthy young adults obviously sets limits to the practical usage of these findings. However, administrating these types of stimuli to the clinical population could cause specific distress, so we suggest a qualitative approach when furthering this line of research.

Conflict of Interest: The authors declare that they have no conflict of interest. 


\section{Reference}

Almashat, S., Ayotte, B., Edelstein, B., \& Margrett, J. (2008). Framing effect debiasing in medical decision making. Patient Education and Counseling, 71(1), 102-107. doi:10.1016/j.pec.2007.11.004

Appelbaum, P.S., \& Grisso, T. (1988). Assessing Patients' Capacities to Consent to Treatment. New England Journal of Medicine, 319(25), 1635-1638. doi:10.1056/ nejm198812223192504

Damnjanovic, K., \& Gvozdenovic, V. (2016). Influence of the probability level on the framing effect. Psychological Topics, 25(3); 405-429; Available from: https://hrcak.srce.hr/169520.

Damnjanović, K. (2013). Framing effect and domain of decision. In Book of abstracts of the Scientific-Professional Conference: Current Trends in Psychology; 2013 October 11-13, Novi Sad, Serbia. Novi Sad, Serbia: Faculty of Philosophy. pp 113-115; Available from: http://psihologija.ff.uns.ac.rs/repository/puni. php?sifra $=$ stup2013081\#page $=115$.

Bigman, C.A., Cappella, J.N., \& Hornik, R.C. (2010). Effective or ineffective: Attribute framing and the human papillomavirus (HPV) vaccine. Patient Education and Counseling, 81, 70-76. doi:10.1016/j.pec.2010.08.014

Blumenthal-Barby, J.S., \& Krieger, H. (2015). Cognitive Biases and Heuristics in Medical Decision Making: A critical review using a systematic search strategy. $\mathrm{Me}$ dical Decision Making, 35(4), 539-557. doi:10.1177/0272989x14547740

Brewer, N.T., Weinstein, N.D., Cuite, C.L., \& Herrington, J.E. (2004).Risk perceptions and their relation to risk behavior. Annals of Behavioral Medicine, 27(2), 125130. doi:10.1207/s15324796abm2702_7

Coulter, A., \& Collins, A. (2011). Making shared decision-making a reality. London: King's Fund.

Covey, J. (2007). A Meta-analysis of the Effects of Presenting Treatment Benefits in Different Formats. Medical Decision Making, 27(5), 638-654. doi:10.1177/0272989x07306783

Dawson, N.V., \& Arkes, H.R. (1987). Systematic errors in medical decision making. Journal of General Internal Medicine, 2(3), 183-187. doi:10.1007/ bf02596149

Edwards, A., Elwyn, G., Covey, J., Matthews, E., \& Pill, R. (2001). Presenting Risk Information A Review of the Effects of Framing and other Manipulations on Patient Outcomes. Journal of Health Communication, 6(1), 61-82. doi:10.1080/10810730150501413

Elwyn, G., Laitner, S., Coulter, A., Walker, E., Watson, P., \& Thomson, R. (2010). Implementing shared decision making in the NHS. BMJ, 341(14 2), 5146-5146. doi:10.1136/bmj.c5146

Fagley, N.S., \& Miller, P.M. (1997). Framing Effects and Arenas of Choice: Your Money or Your Life. Organizational Behavior and Human Decision Processes, 71(3), 355-373. doi:10.1006/obhd.1997.2725

Ferrer, R.A., \& Klein, W.M.P. (2015). Risk perceptions and health behavior. Current Opinion in Psychology, 5, 85-89. doi:10.1016/j.copsyc.2015.03.012

Ferrer, R.A., Klein, W., Lerner, J.S., Reyna, V., \& Keltner, D. (2014). Emotions and health decision making: Extending the Appraisal Tendency Framework to improve 
health and health care. Behav Econ Public Health, Doi: https://doi.org/10.1093/ med/9780199398331.003.0004.

Fischer, G.W., \& Hawkins, S.A. (1993). Strategy compatibility, scale compatibility, and the prominence effect. Journal of Experimental Psychology: Human Perception and Performance, 19(3), 580-597. doi:10.1037/0096-1523.19.3.580

Garcia-Retamero, R., \& Galešić, M. (2010). How to Reduce the Effect of Framing on Messages About Health. Journal of General Internal Medicine, 25(12), 13231329. doi:10.1007/s11606-010-1484-9

Haward, M.F., Murphy, R.O., \& Lorenz, J.M. (2008). Message Framing and Perinatal Decisions. Pediatrics, 122(1), 109-118. doi:10.1542/peds.2007-0620

Horne, R., \& Weinman, J. (1999). Patients' beliefs about prescribed medicines and their role in adherence to treatment in chronic physical illness. Journal of Psychosomatic Research, 47(6), 555-567. doi:10.1016/s0022-3999(99)00057-4

Huang, Y., \& Wang, L. (2010). Sex differences in framing effects across task domain. Personality and Individual Differences, 48(5), 649-653. doi:10.1016/j. paid.2010.01.005

Kahneman, D., \& Tversky, A. (1979). Prospect Theory: An Analysis of Decision under Risk. Econometrica, 47(2), doi:10.2307/1914185

Levin, I.P., Schnittjer, S.K., \& Thee, S.L. (1988).Information framing effects in social and personal decisions. Journal of Experimental Social Psychology, 24(6), 520529. doi:10.1016/0022-1031(88)90050-9

Levin, I.P., Gaeth, G.J., Schreiber, J., \& Lauriola, M. (2002). A New Look at Framing Effects: Distribution of Effect Sizes, Individual Differences, and Independence of Types of Effects. Organizational Behavior and Human Decision Processes, 88(1), 411-429. doi:10.1006/obhd.2001.2983

Mazur, D.J., \& Hickam, D.H. (1996). Patient preferences for management of localized prostate cancer. Western journal of medicine, 165(1-2), 26-30; Available from: https://www.ncbi.nlm.nih.gov/pmc/articles/PMC1307537/pdf/westjmed00347-0028.pdf.

McNeil, B.J., Pauker, S.G., Sox, H.C., \& Tversky, A. (1982). On the Elicitation of Preferences for Alternative Therapies. New England Journal of Medicine, 306(21), 1259-1262. doi:10.1056/nejm198205273062103

Moxey, A., O’Connell, D., McGettigan, P., \& Henry, D. (2003). Describing treatment effects to patients. Journal of General Internal Medicine, 18(11), 948-959. doi:10.1046/j.1525-1497.2003.20928.x

Ozdemir, S., \& Finkelstein, E.A. (2018). Cognitive Bias: The Downside of Shared Decision Making. JCO Clinical Cancer Informatics, 2, 1-10. doi:10.1200/ cci.18.00011

Payne, J.W., Bettman, J.R., \& Johnson, E.J. (1988). Adaptive strategy selection in decision making. Journal of Experimental Psychology: Learning, Memory, and Cognition, 14(3), 534-552. doi:10.1037//0278-7393.14.3.534

Peters, E., Västfjäll, D., Slovic, P., Mertz, C.K., Mazzocco, K., \& Dickert, S. (2006). Numeracy and Decision Making. Psychological Science, 17(5), 407-413. doi:10.1111/j.1467-9280.2006.01720.x

Petrova, D., Garcia-Retamero, R., \& Cokely, E.T. (2015). Understanding the Harms and Benefits of Cancer Screening: A model of factors that shape informed decision making. Medical Decision Making, 35(7), 847-858. doi:10.1177/0272989x15587676 
Reyna, V.F., \& Brainerd, C.J. (1991). Fuzzy-trace theory and framing effects in choice: Gist extraction, truncation, and conversion. Journal of Behavioral Decision Making, 4(4), 249-262. doi:10.1002/bdm.3960040403

Reyna, V.F., Lloyd, F.J., \& Brainerd, C.J. (2003). Memory, Development, and Rationality: An Integrative Theory of Judgment and Decision Making. In S.L. Schneider \& J. Shanteau (Eds.), Emerging Perspectives on Judgment and Decision Research. (pp. 201-245). New York, NY: Cambridge University Press (CUP). doi:10.1017/ cbo9780511609978.009

Reyna, V.F., \& Brainerd, C.J. (1995). Fuzzy-trace theory: Some foundational issues. Learning and Individual Differences, 7(2), 145-162. doi:10.1016/10416080(95)90028-4

Reyna, V.F. (2008). A Theory of Medical Decision Making and Health: Fuzzy Trace Theory. Medical Decision Making, 28(6), 850-865. doi:10.1177/0272989x08327066

Reyna, V.F., \& Brainerd, C.J. (2008). Numeracy, ratio bias, and denominator neglect in judgments of risk and probability. Learning and Individual Differences, 18(1), 89-107. doi:10.1016/j.lindif.2007.03.011

Reyna, V.F., Nelson, W.L., Han, P.K., \& Dieckmann, N.F. (2009). How numeracy influences risk comprehension and medical decision making. Psychological Bulletin, 135(6), 943-973. doi:10.1037/a0017327

Reyna, V.F., Nelson, W.L., Han, P.K., \& Pignone, M.P. (2015). Decision making and cancer. American Psychologist, 70(2), 105-118. doi:10.1037/a0036834

Reyna, V.F., \& Brainerd, C.J. (2007). The importance of mathematics in health and human judgment: Numeracy, risk communication, and medical decision making. Learning and Individual Differences, 17(2), 147-159. doi:10.1016/j.lindif.2007.03.010

Saposnik, G., Redelmeier, D., Ruff, C.C., \& Tobler, P.N. (2016). Cognitive biases associated with medical decisions: A systematic review. BMC Medical Informatics and Decision Making, 16(1), doi:10.1186/s12911-016-0377-1

Slade, M. (2017). Implementing shared decision making in routine mental health care. World Psychiatry, 16(2), 146-153. doi:10.1002/wps.20412

Steginga, S.K., Occhipinti, S., Gardiner, R.A., Yaxley, J., \& Heathcote, P. (2002). Making decisions about treatment for localized prostate cancer. BJU International, 89(3), 255-260. doi:10.1046/j.1464-4096.2001.01741.x

Stokes, W.A., Bronsert, M.R., Meguid, R.A., Blum, M.G., Jones, B.L., Koshy, M., . . Rusthoven, C.G. (2018). Post-Treatment Mortality After Surgery and Stereotactic Body Radiotherapy for Early-Stage Non-Small-Cell Lung Cancer. Journal of Clinical Oncology, 36(7), 642-651. doi:10.1200/jco.2017.75.6536

Marsh, K., IJzerman, M., Thokala, P., Baltussen, R., Boysen, M., Kaló, Z., . . . Devlin, N. (2016). Multiple Criteria Decision Analysis for Health Care Decision Making: Emerging Good Practices: Report 2 of the ISPOR MCDA Emerging Good Practices Task Force. Value in Health, 19(2), 125-137. doi:10.1016/j.jval.2015.12.016

Tversky, A., \& Kahneman, D. (1981).The framing of decisions and the psychology of choice. Science, 211(4481), 453-458. doi:10.1126/science.7455683

Wang, X.T. (1996). Framing Effects: Dynamics and Task Domains. Organizational Behavior and Human Decision Processes, 68(2), 145-157. doi:10.1006/ obhd.1996.0095 
Wang, X.T. (1996). Domain-specific rationality in human choices: Violations of utility axioms and social contexts. Cognition, 60(1), 31-63. doi:10.1016/00100277(95)00700-8

\section{Okvir i naziv medicinskog tretmana i njihov uticaj na zdravstvene odluke}

\section{Kaja Damnjanović}

Univerzitet u Beogradu, Filozofski fakultet

\section{Sandra Ilić}

Univerzitet u Beogradu, Filozofski fakultet, Odeljenje za psihologiju, Laboratorija za eksperimentalnu psihologiju

\section{Predrag Teovanović}

\section{Univerzitet u Beogradu, Fakultet za specijalnu edukaciju i rehabilitaciju}

Odluke o ličnom zdravlju protežu se od svakodnevnih i lakih, kao što je odluka o uzimanju vitaminskog suplementa, do onih koje se donose u situacijama kada je prisutna životno ugrožavajuća bolest. Pacijenti koji donose odluku o izboru tretmana suočavaju se sa specifičnim izazovima i imaju poteškoća da razumeju statističke podatke o mogućim ishodima alternativnih tretmana, o verovatnoći i o rizicima. Ova problematika je posebno značajna u kontekstu prakse zajedničkog odlučivanja, u kojoj i pacijent, a ne samo lekar, donosi odluku o tome na koji način će se tretirati bolest. Cilj ove studije bio je da se ispita uticaj naziva tretmana u zadacima odlučivanja u uslovima rizika. Efekat okvira rizičnog izbora se odnosi na sistematsku promenu redosleda preferencija koje su različite po rizičnosti. Do toga dolazi usled naglašavanja različitih aspekata identične situacije prilikom prikazivanja opcija donosiocima odluka. U našoj studiji ispitanici su prinudno birali između nerizičnog i rizičnog tretmana, koji su predstavljeni u terminima dobitka i gubitka. U prvoj eksperimentalnoj situaciji, kao rizična opcija predstavljena je operacija, a u drugoj zračenje. U trećem eksperimentu, nazivi tretmana su zamenjeni apstraktnim oznakama A i B. Rezultati pokazuju statistički značajnu razliku u proporcijama rizičnih odgovora između tri eksperimentalne situacije. Efekat okvira je registrovan u prvom i drugom eksperimentu; $\mathrm{u}$ prvom umerenog, a $\mathrm{u}$ drugom većeg intenziteta. Kada biraju između operacije i zračenja na ispitanike utiče naziv tretmana, ali to ne objašnjava celokupnu varijansu. Po pravilu, preferirali su operaciju, a kada je ona prikazana u terminima gubitka, ta preferencija je bila još jača.

Ključne reči: zdravstvena odluka; zajedničko odlučivanje; rizični izbor; efekat okvira; medicinski tretman; hirurška intervencija; zračna terapija; teorija izgleda; teorija mutnih tragova; pacijent 